Island Studies Journal, Vol. 4, No. 2, 2009, pp. 121-138

\title{
Recontinentalizing Canada: Arctic Ice's Liquid Modernity and the Imagining of a Canadian Archipelago
}

Phillip Vannini

Royal Roads University, Victoria BC, Canada

Phillip.Vannini@Royalroads.ca

Godfrey Baldacchino

University of Prince Edward Island, Charlottetown PE, Canada

gbaldacchino@upei.ca

Lorraine Guay

Quebec City QC, Canada

lguay01@hotmail.com

Stephen A. Royle

Queen's University Belfast, Northern Ireland, United Kingdom

s.royle@qub.ac.uk

Philip E. Steinberg

Florida State University, Tallahassee FL, USA

psteinberg@fsu.edu

Abstract: Studying mobile actor networks of moving people, objects, images, and discourses, in conjunction with changing time-spaces, offers a unique opportunity to understand important, and yet relatively neglected, "relational material" dynamics of mobility. A key example of this phenomenon is the recontinentalization of Canada amidst dramatically changing articulations of the meanings and boundaries of the Canadian landice-ocean mass. A notable reason why Canada is being re-articulated in current times is the extensiveness of Arctic thawing. The reconfiguration of space and "motility" options in the Arctic constitutes an example of how "materiality and sociality produce themselves together." In this paper we examine the possibilities and risks connected to this recontinentalization of Canada's North. In exploring the past, present, and immediate future of this setting, we advance the paradigmatic view that Canada's changing Arctic is the key element in a process of transformation of Canada into a peninsular body encompassed within a larger archipelagic entity: a place more intimately attuned to its immense (and growing) coastal and insular routes.

Keywords: Arctic historical geographies, Arctic Archipelago, Climate Change, Canadian regions, island studies, mobilities, Northwest Passage.

(C) 2009 - Institute of Island Studies, University of Prince Edward Island, Canada 


\section{P. Vannini et al.}

\section{Introduction}

Over recent decades, social scientists have advanced a new paradigm which emphasizes the dynamic constitution of all social relationships through the mediation of distance and the growth of interconnectedness (Urry, 2007: 46; Hannam et al., 2006; Sheller \& Urry, 2006). Mobility's multiple forms - or mobilities - are being increasingly conceptualized as emergent, relational "socially produced motion" (Cresswell, 2006). These scholars argue for the declining validity of traditional definitions of concepts like society and culture, with their connotations of place-bound "metaphysical sedentarism" (Cresswell, 2006: 26) and thus their tendencies to privilege fixed roots, frozen in time-space, over routes (Urry, 2000; Clifford, 1997). Empirical research and theorization have been moving in step to shed light on the relevance of people's embodied travel and the movement of goods, as well as virtual and imaginative travel. Mobility, in the words of Cresswell (2006: 4), is now "more central to both the world and our understanding of it than ever before."

In spite of this progress, the study of mobilities has hitherto mostly concentrated on movement through fixed time-space, as opposed to movement contiguous with fluid timespaces. Furthermore, the literature on mobilities regularly focuses on land-based movement and traditional continental and sub-continental territories, at the expense of processes occurring on seas, coasts, and islands. Studying mobile actor networks of moving people, objects, images, and discourses, in conjunction with changing time-spaces, and within coastal and insular contexts, offers a unique opportunity to understand important, and yet relatively neglected, "relational material" dynamics of mobility (Law \& Mol, 1995) and extend our understanding of those dynamics to coastal and island spaces. A key example of this phenomenon is the recontinentalization of Canada amidst dramatically changing articulations of the meanings and boundaries of the Canadian landice-ocean mass.

A notable reason why Canada is being re-articulated in current times is the extensiveness of Arctic thawing and the genesis of new routes to Arctic islands. The reconfiguration of space and "motility" options (Kaufman, 2003) in the Arctic - as a result of the opening of new passages and the closing of old ones, the re-definition of physical distances amongst Arctic islands and between islands and the North American and European continents, the strategic reappraisal of peripheral regions, the implications of rising water levels on coastal communities, the transformation in sea-travel routes, and the imaginative re-articulation of images of the Canadian subcontinent - constitutes an example of how "materiality and sociality produce themselves together" (Law \& Mol, 1995: 274). From a relationalmaterialist perspective, glacial shifts are not separate and independent from human mobilities. Rather, we see emergent in the Arctic a spatiality akin to that attributed by Massey (2006a) to a world characterized by shifting tectonic plates. In such a world, wherein space itself is continually mobile and under construction, it makes no sense to think of movement as a process wherein time unfolds across space-wherein a foreground of objects moves across a stable background of environment. Rather, in such a world, time, space, islands, and mainlands constitute each other as the mobile foreground becomes the background and vice versa (Massey, 2006b). The melting of Arctic ice is a material, social, and symbolic re-articulation of mobile relations between mobile people and their fluid 
marine and terrestrial environment. This point of view conceptualizes both social and material transformations in the Arctic as an emergent process of reterritorialization (Deleuze \& Guattari, 1986) and - provocatively — as a form of the potential future advance of "liquid modernity" in the Arctic (Bauman, 2001; 2007). The pun is intended.

Drawing upon an eclectic body of information available on the topic, the research literature in the fields of mobilities and human geography - especially with regard to island studies (e.g. Baldacchino, 2007; Royle, 2001) and ocean-space studies (Steinberg, 2001) - and borrowing ideas from a diverse theoretical corpus that includes social constructionism, social ecology, and actor-network theory, in this paper we examine the possibilities and risks connected to the recontinentalization of Canada's North. In exploring the past, present, and immediate future of this setting, we advance the paradigmatic view that Canada's changing Arctic is the key element in a process of transformation of Canada into a peninsular body encompassed within a larger archipelagic entity: a place more intimately attuned to its immense (and growing) island region, and coastal and insular routes. Spawned out of common exploratory interests originating from different disciplinary perspectives, our paper is programmatic rather than analytical, perhaps even speculative more than empirical - especially given the paucity of relevant social scientific data. By envisioning and outlining avenues for research in this field, we hope to stimulate dialogue and interest in future research.

\section{Assembling a New, and yet So Old, Archipelago}

Amongst some of the most under-examined "metageographical" (Lewis and Wigen, 1997) concepts in the field of island studies is that of "archipelago." The most common definition of the concept "archipelago" is "a group of islands." This is a simple, yet powerful idea; archipelagic formations become so common and so entrenched in popular discourse and imagination that to conceive of individual islands separately from the archipelagos they make up frequently is inconvenient, and it would cause one to miss the point that at times archipelagos are at the very core of important civilizations, collective identities, and nation-states. As a notable historical example of the material and symbolic power of archipelagos one can think of Thalassocracies (meaning: ruling of, and from, the sea) such as the ancient Phoenician network of trade routes an merchant cities in the Mediterranean, the Minoan civilization, the rule of the Republic of Venice in the Middle Ages, the dominance of the Repubbliche Marinare (Pisa, Genoa, Venice, and Amalfi) also in the Mediterranean, as well as-here in North America - the Haida Nation and the Tlingit Confederation (both known for having ruled over British Columbia's central and northern coast and islands) (see Horden and Purcell, 2006). The power of the Caribbean archipelago in defining collective identity and a shared sense of Diaspora is another notable example of the cultural relevance of archipelagos.

Form a cognitive perspective, revealing of the power of the archipelago concept is also the fact that some groups of islands - despite their geographical proximity and environmental similarity - are never thought of as archipelagos, such as the countless islands of British 


\section{P. Vannini et al.}

Columbia's central coast, or those lying at the mouth of Canada's St. Lawrence River. On the other hand those islands that do get clustered into archipelagos almost lose their individual identity (think for example of the hundreds of islands making up the "Queen Charlotte Islands"). The archipelago concept is a unique type of social construction: an "assemblage" (Deleuze \& Guattari, 1986) whereby "bits and pieces achieve significance in relation to others" (Law \& Mol, 1995: 276).

An assemblage is a gathering, a collection, a composition of things that are believed to fit together. To assemble is to act: to actively map out, select, draw together, and to conceive of individual units as a group. Deleuze and Guattari use the example of constellations: assemblages of heavenly bodies that, like the Big Dipper, only take a recognizable form when their wholeness arises out of a process of articulating multiple elements by establishing connections amongst them. An archipelago is similar in nature to a constellation: conceptualizing an archipelago as an assemblage draws our attention to the ways in which "practices, representations, experiences, and affects articulate to take a particular dynamic form" (Slack \& Wise, 2005: 129). Archipelagos, therefore, are inventions whose validity and usefulness is contingent on the dynamics of their formations and the particulars of their contexts. Archipelagos, in other words, are not essential properties of space but instead are fluid cultural processes dependent on changing conditions of articulation or connection.

The social construction of an archipelago, or its assemblage, can be said to be an act of “territorialization" (Deleuze \& Guattari, 1986). But the very idea of territorialization seems somewhat partial and biased in favor of landlocked territories. A concept more applicable to our case is that of "continentalization." The concept of continentalization de-emphasizes terra (e.g. dirt), and implicitly highlights more the marine elements of space. The concept of continentalization also focuses more directly than that of territorialization on the social construction of continents as metageographical ideas. The idea that continents are essential, bounded units is intertwined with the idea that they are "large, continuous, discrete masses of land ideally separated by expanses of water" (Lewis and Wigen 1997: 21).

By continentalizing a space in the form of an archipelago, we foster a new metageographical "metaphor" (Lakoff \& Johnson, 1980): a new way of thinking and of sensing the material and social world, a new body of knowledge and praxis, and thus a new "particular constellation of articulations that selects, draws together, stakes out, and envelops a territory that exhibits some tenacity and effectivity" (Slack \& Wise, 2005: 129). In our case, the archipelago concept allows us to better articulate networks of ice flows, islands, and oceans - and thus to redefine the continental identity of North America and the nation-state definition of Canada as a dominant mainland, while at the same time to include in the same network Arctic and Polar regions that "belong" to continents other than North America.

When elements - material and social-are articulated anew, a novel vision is put into practice. Such transformation is what Deleuze and Guattari refer to as deterritorialization and reterritorialization: the processes whereby articulations are disassembled and 
reassembled in novel ways. The same of course applies in the case of decontinetalization and recontinentalization. To be sure, a particular continentalization is not necessary or inevitable; multiple and competing options for assembling connections together always exist and are often in conflict with one another. In positing a new-but, as we will argue further below, old as well-articulation of Canada as an archipelago we constructively engage in a process of assemblage: a re-continentalization based on both changing material conditions and a reinterpretation of Canada's identity as a land-ice-ocean mass.

As Canada is the second largest country in the world, after Russia, a "continental" definition of the territory based on its great physiographic and geo-political regional units is practical, and indeed common amongst, arguably, most Canadians. But what this view ignores is the fact that Canada also has the longest shoreline in the world, with three oceans (Pacific, Arctic, Atlantic), the most extensive lake region in the world (including the Great Lake region, Great Bear Lake, Great Slave Lake, Lake Winnipeg, as well as countless others), a highly trafficked and extensive fluvial network (ranging from the St. Lawrence in the South to several rivers used for transportation throughout the Arctic North), as well as the largest number of islands of any country in the world. Indeed, all four extreme compass positions of the country are delineated by islands ${ }^{1}$. In light of this condition, traditional "continental" articulations of Canada seem inadequate to capture a fulsome sense of the country; indeed, they could be alternatively seen as deeply complicit in the process of relegating marine, insular, and littoral Canada to the margins of national, cultural, and political consciousness. As an alternative, we propose a recontinentalization of Canada wherein what typically is conceived of as a continental land-mass is instead recontinentalized as a large peninsula inside an even larger archipelago - a dynamic assemblage of land, ice, and water whose spatiality is mobile and whose geophysicality is fluid. Within this new articulation, islands and coasts are central rather than peripheral.

\section{Past Assemblages of the Canadian Archipelago}

Archipelagic or island-centric conceptualizations of Canada are not new. For example, buying or defending islands to delimit these frontiers has been a key preoccupation of colonial powers and governments in what was to become Canada. Canadian islands have been used as fortresses, prisons, secret and public scientific research stations, and jumpingoff points for exploration. Long before the Europeans came to Canada, many characteristics of islandness were closely associated with aspects of the North American continent's identity. To be sure, the continentalization of Canada occurred slowly over time. The central global position occupied by the Eurasian continent in European minds was such that North America and especially Canada were seen as smaller in size than they truly were, and thus undeserving of continental status. The historical quest for quick passages through and around Canada evidences the notion that Canada was an archipelago first and only a land-based continent later.

\footnotetext{
${ }^{1}$ Pelee Island, in Lake Erie, was the southernmost point in Canada until July 2001, when Parks Canada bought Middle Island, which, although in Canadian waters, was under private U.S. ownership. Both islands are now part of a Canadian national park: http://www.middlebass2.org/Middle_Island_1999.shtml.
} 


\section{P. Vannini et al.}

In the cosmology of the natives of what came to be known as Upper Canada (roughly what is now southern Ontario), for example, islandness had a very special significance. The word wendat - the name of the five confederated aboriginal nations who called the region home-means "dwellers of the peninsula" or "island inhabitants" (Heidenreich, 1971: 86). According to their cosmology, this territory, called Wendake, was formed in prehistoric times as an island limited by three lakes and a huge swamp to the south. Moreover, the world itself was conceived as an island on a turtle's back. As Sioui (1994 : vii, 15, 177, 178) writes: "La Grande Tortue...soutient physiquement et spirituellement notre Grande Île, l'Amérique" [The Big Turtle physically and spiritually sustains our Big Island, America]. Less is known about the Inuit's early conception of land. However, according to the account by Rasmussen (in Saladin d'Anglure, 2004: 21-22), their traditional belief is that other humans existed before the Inuit but that they were drowned when Earth, a floating island on marine waters, turned upside down. After Earth turned back again on itself, two adult males emerged from two pieces of peat. Then one man transformed the other man into a woman. All the Inuit are the descendants of this original couple. It is said that such events happened on Igloolik Island or perhaps Millijjuaq Island, in the Hudson Strait (ibid.: 21-22). Thus, in Inuit cosmology, as in that of First Nations further to the south, the space of the planet was conceived as a series of nested islands.

As mentioned above, early European explorers also placed what was to become Canada within an insular framework. Indeed, even before they put their feet on "Big Turtle Island," Europeans were mentally constructing an insular image of this remote land. During the Renaissance-as Europeans expanded their interest in exploring seas and discovering unknown lands - the island emerged as a ubiquitous trope through which they conceived of alluring lands that lay across (or in) the oceans that lay beyond the continent's shores. Renaissance-era isolarios - atlases of both real and imagined, but always, highly stylized, islands - presented a cosmology wherein, even if the European land mass was a continent, the rest of the world consisted of islands wherein spatial distinction was fused with unique social (or natural) characteristics (Gillis, 2004; Steinberg, 2005). The island theme also notably inspired philosophical works like Thomas More's Utopia (More, 1516/2003). In this writing, after conquering the Abraxa peninsula, King Utopus had the isthmus cut off from the mainland. This symbolic act, which transformed the peninsula into an island, thus aligned this perfect and malleable geographical space with More's political project for a perfect society.

To potential emigrants from Great Blasket Island off western Ireland, America was known for a long time as "New Island" (O’Sullivan, 1933/1953: 265). Such an island imaginary should not surprise us: after all, at that time, exploring seas to discover new lands often meant the discovery of new islands. In 1496, King Henry VII of England licensed Giovanni Caboto to embark on a voyage of exploration. Writing about this journey in 1497, Lorenzo Pasqualigo noted: 
"Ce compatriote vénitien qui était parti de Bristol dans un petit navire pour aller à la découverte d'îles nouvelles est revenu" [This Venetian compatriot who left Bristol in a small ship to discover new islands has now returned] (quoted in Lacoursière \& Bizier, 1983: 46).

After many attempts, both French and English established settlements on islands along the Atlantic coast. On the "island of Canada," Cartier and Roberval established a fort at Franceroy, a promontory at the confluence of the St. Lawrence and Cap-Rouge rivers in 1542, although the onset of scurvy and violent attacks by the Iroquois forced the abandonment of the fort the following year. Similar uses of islands as forward positions for nascent colonization schemes were occurring throughout the Americas during this period. Nicolas Durand de Villegaignon set up a refuge for Huguenots (French Protestants) on the island that bears his name, close to modern day Rio de Janéiro, Brazil, in 1555, only to be overtaken by the Portuguese 5 years later, and thus forced to relocate to Charles Fort on Parris Island (in the Beaufort archipelago of what is now South Carolina) (Thevet, 1983: 14-18). In 1584, on Roanoke Island, north of Cape Hatteras, the first English settlement in North America was founded by Sir Walter Raleigh. In the Gulf of St. Lawrence, Charles Leigh arrived in the Magdalen Islands and attempted to establish a colony of Protestants in 1597-though he had to abandon his mission as the island was already occupied by Basques, Bretons, and natives (quoted in Lacoursière \& Bizier, 1983: 72). In 1598, the Marquis de La Roche established a colony on Sable Island (Armstrong, 1988: 25-26). What all these and similar events demonstrate is how Europeans were looking for/to islands to make fresh starts in life and create new settlements (Royle, 2001). This is a typical dynamic of individual and social reterritorialization, a dynamic of search and exploration for new routes (Clifford, 1997) and the settlement of new "moorings" (Sheller \& Urry, 2006). Even if these moorings did not survive very long, these small colonies were part of a larger quest for new routes to islands, places where virtually everything was possible and that always lay just beyond the horizon (Guay, 2003: 114). The crossing of the Atlantic was an auspicious project that carved new sea routes to project European ideals and their search for a land of liberty in an unknown world. North America was thus not only a material constellation of islands, but also a deeply symbolic archipelago: a utopian and providential one. By transforming the boundaries of this fluid archipelago, Europeans sought to remake the world: a rare opportunity for a fresh start, hoping to avoid the mistakes of their past.

This process of continentalization of the American archipelago took a sharp turn with the "wayfinding" (Peters, 2006) of the navigator, explorer, and cartographer Samuel de Champlain. Champlain knew that the Americas formed a continental barrier between the oriental sea and the occidental sea. Still, surprisingly, he wrote in 1599 that, if the isthmus of Panama was severed, "all America would be in two islands" (Giguère, 1973: 45). Thus, ideas of the Americas as continents were beginning to emerge.

For Champlain, an island could have a very large size, even a continental scale. But it could also be small and isolated. Thus Champlain, like many of his predecessors - and three years before the English would build James Fort on Jamestown Island-chose to 


\section{P. Vannini et al.}

establish his first colony on a small island: Sainte-Croix (Dochet Island), between present day Maine and New Brunswick (Kelso \& Straube, 2004: 12). On that piece of land, the European "construction" of the Canadian archipelago was started in 1604. One could also attribute to that same date the beginning of the end to the "Big Turtle Island" idea.

\section{From the Past to Present Canadian Archipelago: Re-assembling the Nation from the Arctic}

A new decontinentalization of Canada and recontinentalization of the Arctic is unfolding. This phase - occasioned by the potential opening of the Northwest Passage, as well as offshore Arctic mineral extraction opportunities - is leading to the deterritorialization of Canada as a continental land mass, and to its recontinentalization as an archipelagic assemblage of land, islands, ice, and water that is more attuned with its Northern coast and islands, and less dependent on its terrestrial articulation with the South.

Today, the Canadian Arctic region is most often defined as the territory located above the $60^{\text {th }}$ parallel North - or, as some would have it, above the tree line. The area includes the uppermost reaches of Quebec and Labrador, and, chiefly, three territories: Yukon, Nunavut, and the Northwest Territories. As a whole, the Canadian Arctic in 2001 was home to about 110,000 people dispersed across about seventy-five communities but concentrated in the capital territorial cities of Whitehorse, Iqaluit, and Yellowknife. "The North"- as Canadians refer to the Arctic region-also comprises the Arctic Archipelago: a land area of 1,424,500 $\mathrm{km}^{2}$ that comprises a network of 36,563 islands, 94 of which are larger than $130 \mathrm{~km}^{2}$ (or 50 square miles), and their contiguous waters. At a headcount of 9,653, Baffin Island is the most highly populated island in the Arctic Archipelago, significantly ahead of Kitlineq or Victoria Island (1,707), Qikiqtaq or King William Island (960), Southampton Island (721), Ellesmere Island (168), and Banks Island (114). ${ }^{2}$ The entire Arctic Archipelago extends about 2,400 km longitudinally-from the Beaufort Sea on the west side, to Greenland on the east - and about 1,900 km from Cape Columbia, the northernmost point on Ellesmere Island, to the nearest mainland shore point.

Given the underdeveloped character of the Arctic road network, sea routes matter greatly. Marine transportation connects the Arctic Archipelago with the Pacific and the Atlantic shores of Canada, as well as with the port of Montreal via the St. Lawrence River. An unconventionally drawn map of Canada which privileges the northern polar regionsproduced by NTCL, an Arctic shipping company-represents effectively the littoral, insular, and peninsular nature of the country. Crucial for the insightfulness of this archipelagic vision of Canada - centered around the North, rather than the Southern border with the United States - is the Northwest Passage (see Figure 1).

\footnotetext{
${ }^{2}$ All demographic data are obtained from Statistics Canada and refer to 2001.
} 
Figure 1 - An Archipelagic Vision of Canada.

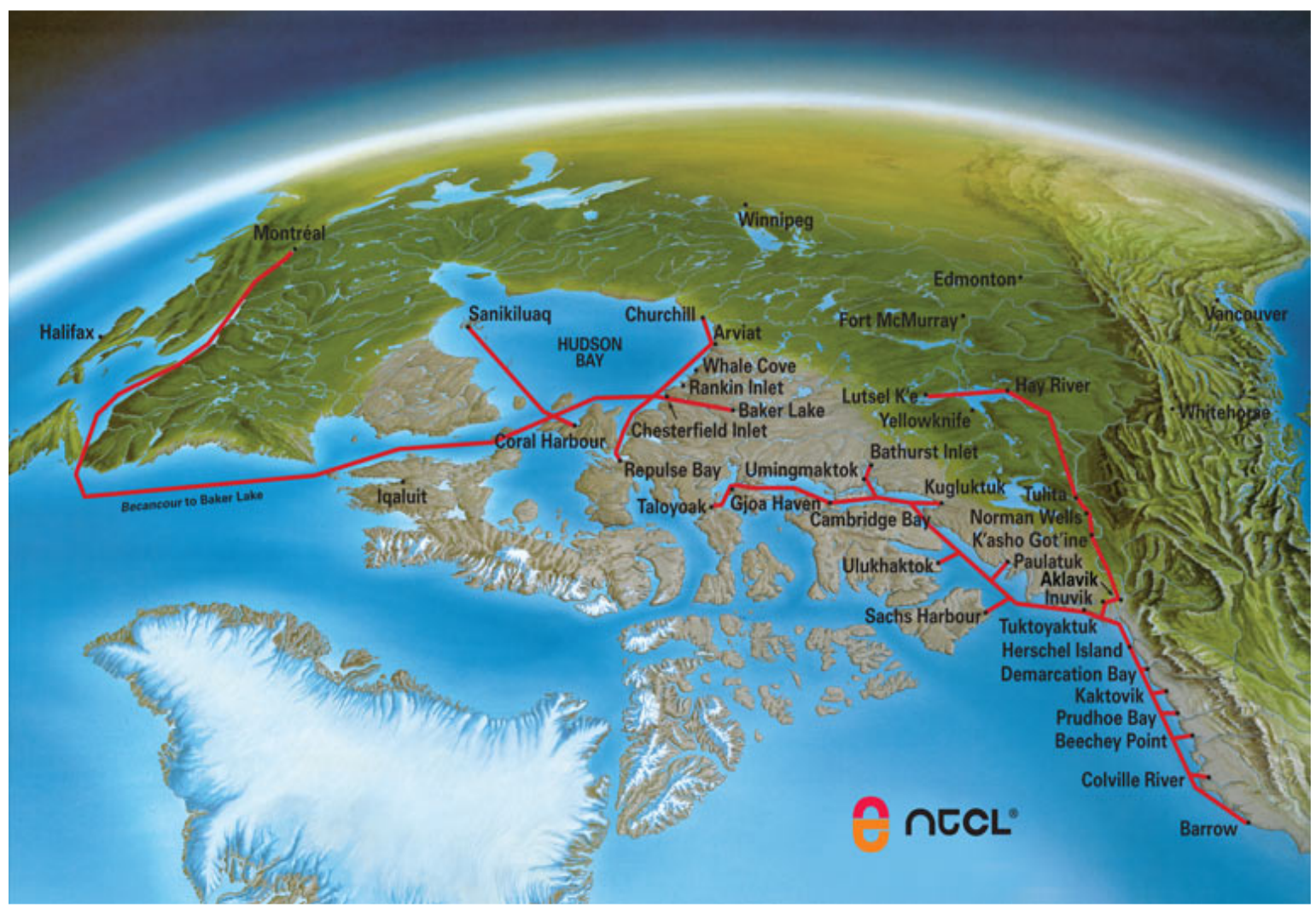

Source: Northern Transportation Company Ltd. - http://www.ntcl.com/

The Northwest Passage is a vast network of about half a dozen major sea routes meandering through various Arctic islands, the Canadian mainland, and the U.S. state of Alaska, connecting the Atlantic with the Pacific through the Arctic Ocean. At their easternmost and westernmost points, these routes extend farther to such waterways as the Arctic Bridge: a sea route that connects the Russian port of Murmansk to the Hudson Bay port of Churchill, in Northern Manitoba. The potential of exploiting these networks for marine navigation, and in particular shipping, has long lured explorers to these treacherous waters. Yet, the presence of fast-moving annual ice and the constant threat of floating ice islands have, until recently, restricted access only to the stout-of-heart adventurer and the most heavily fortified deep sea ships and icebreakers.

The appeal of Arctic navigation continues to seduce the imagination of individual adventurers, public groups and private companies worldwide. Shipping through the Northwest Passage would constitute a significant shortcut—ranging for most stakeholders at around $5-7,000 \mathrm{kms}$. For example, the distance from London to Tokyo through the Panama Canal is $23,000 \mathrm{kms}$ and $21,000 \mathrm{kms}$ through the Suez Canal, whereas it would be only $16,000 \mathrm{kms}$ through the Northwest Passage. The considerable savings in time and money that the route offers have recently resulted in a spike in exploratory commercial 


\section{P. Vannini et al.}

traffic and sparked interest in development. Climate change-fueled Arctic ice shrinkage, in particular, has also made Arctic sea mobility considerably easier. Up until the 1990s, the Northwest Passage was navigable only from late June to early October. More recently, navigation has begun earlier in June, or even in late May, and continued much later into October. Other signs that ice-melting is making navigation easier abound. In 2000, the Canadian patrol boat St. Roch II managed to cover the Northwest Passage from West to East in only nine weeks, without being ever significantly obstructed by ice. On September 1, 2001 the diesel-powered $14.3 \mathrm{~m}$ sailboat Northabout captained by Jarlath Cunnane completed the crossing East (Ireland) to West (Bering Strait) in a record 24 days, only to then return to Ireland via the Northeast Passage (Russia's Northern Sea Route)-thus completing the first circumnavigation of the North Pole by a lone sailboat. Many have questioned the long-term prospects for the Passage as a route for cross-polar navigation; as ice melts the sea-route across the North Pole and the Northern Sea Route along the coast of Russia would both be even shorter and probably less treacherous than the Northwest Passage (Brighan, 2008; Holland et al., 2006). However, the melting of waters around Canada's Arctic islands has already begun to facilitate journeys between these islands, between Canada's islands and the Canadian peninsula, and between Arctic Canada and the rest of the world. On 17 October 2007, the port of Churchill received its first shipment from Murmansk, Russia (CBC, 2006). And now shipping from the West Coast of Canada has become both possible and in some cases practically convenient. Thus, even if some of the media hype concerning the future of the Northwest Passage as a potential alternative to the Panama Canal is overblown, the thawing of waters in Canada's North is still likely to have a significant impact on Canada's repositioning as an archipelagic nation.

Notable climate change effects in the Arctic include permafrost reduction and decreases in sea ice - both conditions that have led interested parties to map out the future development of Arctic motility. Beside the aforementioned Russian interests and the announcement of the German group Beluga-which plans to begin shipping to Japan via the Northwest Passage in 2009-US shipping companies have seriously begun lobbying American and Canadian federal and local governments to invest in the logistical upgrading of Northern routes. For instance, George Newton, then chairperson of the US Arctic Research Commission, has argued that shipping companies interested in saving on traveling time and cutting costs "need search and rescue that fall on those ports [...] voyage repairs [...] the ability to manage traffic in an effective fashion and ice breakers" (CBC, 2006). Extensive port upgrades are also needed. Arctic natural harbours are extremely shallow. Due to the paucity of wharves, ships currently must anchor up to four miles out at sea and employ small barges to load and unload their cargo on rocky beaches. With continuing reductions in ice year-round and predictions for entire summer seasons free of ice by as early as 2013, the restructuring of Canada's infrastructure looms ever close at the horizon. 


\section{The Future of the Arctic Archipelago and Canada's Changing Transport Infrastructure}

The infrastructures of social life are critical in the study of mobility as they constitute the very assemblages and ecological systems that enable movement (Star, 1999). Infrastructures provide people with the most basic structures of expectation: the "'spaces of anticipation' that the journey can be made, that the message will get through, that the parcel will arrive" (Urry, 2007: 12-13). The infrastructure of goods distribution is one such system. It allows for predictability, repetition, and, ultimately, for the institutionalization of routines, habits, and "profoundly mundane" rituals (Star, 1999: 379). Shopping for example, at least for most residents of North America, is such a daily routine and even a mindless chore. For residents of the high Arctic, however, things are much different. Traditionally - at least until the middle of the $20^{\text {th }}$ century - procurement of basic survival goods such as food and clothing would be the centre of seasonal patterns of hunting and gathering. More recently, however, the process of resupply has been replaced by a new performative practice: the annual sealift, a commercial ritual by which Northern communities are supplied with all the consumer goods deemed necessary for daily life. ${ }^{3}$

Except for some shipments of food and other perishable or urgent items which take place via air cargo, all of Arctic life's material needs are met by sealift-participating container ships. Three main companies provide sealift services: NTCL, NSSI, and NEAS —operating ocean cargo ships from Vancouver, Montreal, and Churchill. Some inland communities in the Northwest Territories are instead served by river cargo ships. Company schedules vary by community, but in general each company resupplies a community only once a year: an event that requires careful planning. Pfeiff (2007, no page) - in what could be the only quasi-ethnographic reflection on the topic (for more general references, see McCalla, 1994; Van der Zwaag \& Lamson, 1990) - gives us a vivid impression of this unique ritual for the community of Kugaaruk, Nunavut:

"Every April, Sidney and Tess Rodnunsky sit at their kitchen table calculating how much toilet paper their family of four will use in the coming year. "We hate to run out, so we figure on six rolls a week," says Sidney, the school principal in this eastern Arctic village of 688. On a form from Marché Turenne Inc., a Montrealarea cargo expediter, the couple puts down their order and moves on. How many jars of pickles will they go through in twelve months? How many boxes of laundry soap? Bags of Halloween candy? Then they send off the mother of all grocery lists and wait."

On a yearly basis, sealift cargo vessels distribute about 100,000 tonnes of supplies to high Arctic communities. Large containers are unloaded from ships, loaded onto barges, and then dropped on community beaches, where forklifts hastily pick up and distribute goods to homes, the community store(s), nursing station, police outpost, school, and whatever

\footnotetext{
${ }^{3}$ While some goods may be available in the community store, ordering supplies through sealift guarantees wider choice, lower prices, and higher control over their availability. A higher number and diversity of stores exist in larger centres such as Iqaluit and Rankin Inlet.
} 


\section{P. Vannini et al.}

other public institutions may be. The significance, both symbolic and material, of sealift cannot be missed. The rocky beaches of otherwise quiet and peaceful communities suddenly are abuzz with activity. The atmosphere has somewhat of a Christmas feel, as Pfeiff (ibid.) implies in her description:

"As soon as the barge touches the beach, forklifts move in to unload it, grabbing pallets teetering with wooden crates and scooting up the hill to drop them at the Coop's cargo bay, where they quickly stack up. Pried open with crowbars, they are emptied by a column of human haulers hired for the occasion. Kids crawl all over the crates and cheer when the thirty-three tonnes of pop arrive — they drink it at breakfast, lunch, and dinner. "It retails for three dollars a can, and it will be gone by January," says Co-op manager Eric Baxter."

Boxes of soda pop and endless other resources are brought indoors by adults and stacked in house rooms - generally known as "the sealift room"-dedicated to supplies. Sometimes supplies overflow throughout the rest of the house, as one of Pfeiff's (ibid.) interviewees reveals: "We just put tablecloths over boxes of canned food and use them as end tables."

Ritual practices like the sealift vividly demonstrate how different places are "performed" in unique ways and how "they are produced as much as they are producing" (Cresswell, 2002: 22) of the meanings of community and identity. Significantly for our argument here, the sealift is a particularly archipelagic place-producing (and place-presenting) practice. Not unlike the train passage under the Channel Tunnel described by Cosgrove (2007), "crossings" such as the Northwest Passage have the power to dissolve metageographical boundaries such as those between "the Arctic" and mainland Canada, between the North and the South, or between the Polar region and the rest of the continent. The progressive opening of the Northwest Passage - together with the crossings it will facilitate and the consequences it will generate- has first and foremost the power to destabilize existing relationships between mainlands and islands, between ice and land, between oceans and continents, and between terra firma and terra infirma. Hence, the recontinentalization emerging out of these process has the potential to re-inscribe "boundedness, otherness, and passage" itself (Cosgrove, 2007: 16),

Through the construction of infrastructures-in-place-infrastructures that are specifically designed to make connections across island, water, and peninsular spaces - the community establishes the environment through which it can engage in the everyday activities by which its inhabitants reproduce the community's archipelagic identity. To expand on a theme that prevails in both the mobilities and the critical island studies literatures, the experience of the sealift - a practice by which isolated Arctic island communities produce community through rituals of connection-is evidence of the fact that places and communities are neither synonymous with rootedness, permanence, and closure to the outside world nor with the endless circulation, unlimited flow, and unattached nomadism that critics like Augé associate with uniform "non-places" (Augé, 1995). 
Although we define the identity of these Arctic hamlets as specifically archipelagic, we do not mean to suggest that there is any one archipelagic culture, just as there is not any one, specific way of making connections across islands, water, ice, and peninsular mainland. Indeed, as the Canadian North undergoes climate change, with the rise of new shipping opportunities noted above, it is likely that Canada's archipelagic nature will undergo significant transformation. Although we expect Canada's archipelagic characteristics to intensify, the way the country is experienced is likely to undergo significant change. Put another way, an archipelago is a social construction that encompasses a large body of social practices (many of which are associated with mobilities that join spaces with various geophysical characteristics). Indeed, the nature of an archipelago as a set of practices is itself mobile.

\section{The Future of the Canadian Archipelago: A New Vision of/for Canada}

While the national anthem of Canada includes a reference to "the true north, strong and free," and even though Canada has at times romanticized the North, it has largely ignored this region in more senses than one: not just out of benign strategic, economic and infrastructural neglect (Huebert, 2003), but as a distant idea, largely imagined space/hinterland that is almost foreign and alien to its national identity. What is largely an incidental understanding of this geography by most Canadians limits any association of this space with the national psyche, for all its idealized images of the region as a hearth of energy production, environmental harmony, and noble savages (Fienup-Riordan, 1990; Wynn, 2007: 318).

Beside the North, as we have argued in this paper, Canada's coastline has long remained in the back of Canadian's consciousness. Although the Canadian coastline is more than 245,000 kilometers $(152,000$ miles) long, most of it has not been inviting to development. Of course, early European settlement in North America was invariably and necessarily coastal: possessions on both West and East coasts of North America were initially driven by the need to search for, and secure, safe harbours and lucrative fishing grounds, rather than arable lands (Gillis, 2007: 12). But soon, and thanks to its more unforgiving climate and sparser populations, Canada-even more and faster than the United Statesestablished itself as a continental nation (Harris, 1997). The land rather than the sea became the source of livelihood and roads and the railway soon became the key means of national transportation. It is therefore far from unsurprising that both the Trans-Canada Highway and the Canadian Pacific Railway lie at the very core of Canadian national identity and the collective imagination of Canada's nation-space.

In light of Canada's inland and southward orientation, it may seem odd to suggest that such a geo-political assemblage should or could change. Indeed the fundamental shifts in worldwide energy and agricultural prices that characterized the first half of 2008 solidified Canada's inland West - Northern Alberta and Saskatchewan in particular - as the site, albeit temporarily, of windfall profits in oil, gas, potash, and grain. And yet, as Simpson (2008) predicted in those dizzy months which now seem so distant: 


\section{P. Vannini et al.}

"The hardest thing in politics is to plan ahead.... The boom out West is both a lure and a trap."

The centre of gravity of the country remains stuck in the tar sands, the grain fields, and (desperately these days) the Ontario-based automobile factories. As Finance Minister Jim Flaherty informed Canadians, when referring to the nation's vulnerability amidst the 2008 world economic slowdown: "We're not an island" (Cowan, 2008).

And yet, Canada could begin to conceive of itself as an archipelago. What is needed for that to happen, and remains even more elusive and fantastical these days, is a recontinentalizing imagination, a travail (Peters, 2006) of imaginative and embodied mobility that reconciles Canada's destiny with its other inherent and incipient geographies. Unlike the citizens of the U.S., Canadians appear uncertain of whether, and to what extent, to embrace the "sea frontier", 4 preferring the smug comfort of large urban areas (but see MacGregor, 2007), possibly out of a subdued embarrassment of how they engaged with the indigenous communities in their wilderness (after Turner, 1920). And yet, the opening of the Arctic invites us to entertain another "opening," a new materiality, and another type of frontier: an archipelagic one. The expanding and reconstituting of our understanding of Canada's borders and frontiers away from hitherto narrow, terrestrial, and continental definitions may permit an embracing of their implications for a broader politics of sovereignty, citizenship, socio-spatial identity, and power (Lewis, 2005; Mach, 2003). Can Canada conceive of itself as a peninsula, still stuck, for better or for worse, to the North American continent, but supremely cradled between three oceans? And what are the implications of this gestalt switch?

There ought to be no doubt, however, that this shift is not under the control of the Inuit, Dene, and Inuvialuit people habiting in the North and it is thus fraught with dangers for them: the danger that once again their space could be but a "product to be used, to be consumed" and a mere "means of production" (Lefebvre, 1991: 85). Canada's Arctic is an extremely sensitive area and, as Inuit rights activist Sheila Watt-Cloutier (2006) has pointed out, waves of unsustainable development could forever seal the fate of the North, further damaging the already deeply weakened traditions that connect people and places there. A new, borderless Arctic whose traditional symbolic and material boundaries are liquefied by the advance of transnational trade and consumerism is bound to treat the dense web of human-geographic interconnectedness as a mere "obstacle to be cleared out of the way" (Bauman, 2001: 14). Indeed, the melting of Arctic ice that Canadian nationalists have celebrated as bringing about new opportunities for forging connections among Canadian territories and with the outside world may actually further isolate Inuit communities as the ice routes that previously had enabled everyday movements are disrupted by liquid shipping channels. 5 .

\footnotetext{
${ }^{4}$ Frontiers have been a dominant concept in western historiography and geography, as well as in popular discourses. But, in opposition to the land-based notions of traditional frontiers, sea frontiers can be seen as a constantly shifting boundary. We wish to thank an anonymous reviewer for this suggestion.

${ }^{5}$ This concern has led some local residents to oppose plans for using icebreakers to foster water access to mines in Labrador and in the Kitikmeot region of Nunavut.
} 
Canada's Arctic has been hitherto relatively bypassed by many modernizing processes, including the arrival of motility connections quintessentially typical of the modern era such as the automobile, the train, broadband Internet service, cell phone coverage, and the jet, as well as regularly operating cargo ships. Now, however, it may be on the cusp of making a leap into an uncertain condition of liquid modernity (Bauman, 2001, 2007), an "era of disembedding without re-embedding" (Bauman \& Tester, 2001: 89). The progressive opening of the Northwest Passage is an important source of momentum for this change, but it is important to understand that it is not the only driver. Shifting international and domestic economic alliances, changing global commodity prices, struggles over the definition of nation-state boundaries in the Arctic, and many other social forces play important roles in a vastly complex social and material ecology. What is certain, however, is that relations in the North are undergoing a "social melting" (Turner, 2001: 9) that is liable to liquefy all Arctic "nature cultures" (Latour, 1993). Thus, as Canada liquefies and (re)incorporates its coastlines and internal waters within its national imaginary, it may reclaim an archipelagic identity that has long been abandoned in favour of a continental fixity, an identity that favoured notions of permanence in time and space, with solid and incontrovertible distinctions between land and water, between the developable and the undevelopable, and between the social nature that exists within and the wild nature that exists without.

\section{References}

Armstrong, J.C.W. (1988) Samuel De Champlain, Paris, Les Éditions de l'Homme.

Augé, M. (1995) Non-places: Introduction to an Anthropology of Supermodernity, London, Verso.

Baldacchino, G. (ed.) (2007) A World of Islands: An Island Studies Reader, Charlottetown, Canada and Luqa, Malta, Institute of Island Studies, University of Prince Edward Island and Agenda Academic.

Bauman, Z. \& Tester, K. (2001) Conversations with Zygmunt Bauman, Cambridge, Polity Press.

Bauman, Z. (2001) Liquid Modernity, Cambridge, Polity Press.

Bauman, Z. (2007) Liquid Times: Living in an Age of Uncertainty, Cambridge, Polity Press.

Brigham, L.W. (2008) 'Russia's Northern Sea Route and Future Arctic Marine Transportation', keynote address, Annual Meeting of the Association of American Geographers, Boston MA, http://www.mfa.is/media/Utgafa/Breaking_The_Ice_Conference_Report.pdf.

CBC (2006) 'Arctic Shipping Coming Soon, U.S. Expert Says', $C B C$ News, www.cbc.ca/canada/story/2006/06/15/arctic-thurs.html 
Clifford, J. (1997) Routes: Travel and Translation in the Late Twentieth Century, Cambridge MA, Harvard University Press.

Cresswell, T. (2002) 'Introduction: Theorizing Place' in G. Verstraete \& T. Cresswell (eds.) Mobilizing Place, Placing Mobility, Amsterdam, Rodopi, pp. 11-29.

Cresswell, T. (2006) On the Move: Mobility in the Modern Western World, London, Routledge.

Cowan, J. (2008) 'Flaherty won't rule out Federal Deficits', National Post (Canada), October 20, A1.

d'Anglure, B. S. (2004) 'La toponymie religieuse et l'appropriation symbolique du territoire par les Inuit du Nunavik et du Nunavut', Études Inuit, Vol. 28, No 1, pp. 21-22.

Deleuze, G. \& Guattari, F. (1986) A Thousand Plateaus, Minneapolis MN, University of Minnesota Press.

Fienup-Riordan, A. (1990) Eskimo Essays: Yup'ik Lives and How We see Them, New Brunswick NJ: Rutgers University Press.

Giguère, G.-E. (1973) Euvres de Champlain: Tome 1, Montréal QC, Éditions du Jour.

Gillis, J.R. (2004) Islands of the Mind: How the Human Imagination created the Atlantic World, New York, Palgrave MacMillan.

Gillis, J.R. (2007) 'Being Coastal', Coast and Ocean, Vol. 23, No. 1, pp. 10-15.

Guay, L. (2003) À la Découverte des Îles du Saint Laurent, Québec, Éditions du Septentrion.

Cole H. (1997) 'Regionalism and the Canadian Archipelago' in L. McCann (ed.) Heartland and Hinterland: A Geography of Canada, Scarborough ON, Prentice-Hall Canada, pp. 459-484.

Hannam, K., Sheller, M. \& Urry, J. (2006) 'Editorial: Mobilities, Immobilities and Moorings', Mobilities, Vol. 1, No 1, pp. 1-32.

Heidenreich, C.E. (1971) Huronia: A History and Geography of the Huron Indians 16001650, Toronto ON, McClelland and Stewart.

Holland, M.M., Blitz, C. \& Tremblay, L.B. (2006) 'Future Abrupt Reductions in the Summer Arctic Sea Ice', Geophysical Research Letters, Vol. 7, No. 1, pp. 11-23.

Huebert, R. (2003) Northern Interests and Canadian Foreign Policy, Calgary AB, Canadian Defence and Foreign Affairs Institute. 
Turner, F. J. (1920) The Frontier in American History, New York, Henry Holt \& Co.

Kaufman, V. (2003) Re-thinking Mobility, Aldershot, Ashgate.

Kelso, W. \& Straube, B.A. (2004) Jamestown Rediscovery: 1994-2004, Richmond VA, Association for the Preservation of Virginia Antiquities.

Lacoursière, J. \& Bizier, H.-A. (1983) Nos racines, l'histoire vivante des Québécois. Édition commemorative: Vol. 1, Québec, Éditions T.L.M., Livre-Loisirs.

Lakoff, G. \& Johnson, M. (1980) Metaphors We Live By, Chicago IL, University of Chicago Press.

Latour, B. (1993) We have never been Modern, Hempel Hempstead, Harvester Wheatsheaf.

Law, J. \& Mol, A. (1995) 'Notes on Materiality and Sociality', The Sociological Review, Vol. 43, No. 2, pp. 274-294.

Lefebvre, H. (1991) The Production of Space, Oxford, Blackwell.

Lewis, G. (2005) 'Welcome to the Margins: Diversity, Tolerance and Politics of Exclusion', Ethic and Racial Studies, Vol. 28, No. 3, pp. 536-558.

MacGregor, R. (2007) 'Debunking Canada's 'Urban' Legend', The Globe and Mail, November 24.

Mach, Z. (2003) Symbols, Conflict and Identity: Essays in Political Anthropology, Albany NY, State University of New York Press.

Massey, D. (2006a) For Space, Thousand Oaks CA, Sage.

Massey, D. (2006b) 'Landscape as Provocation: Reflections on Moving Mountains', Journal of Material Culture, Vol. 11, No. 1, pp. 33-48.

McCalla, R. (1994) Water Transportation in Canada, Ottawa ON, Formac Publishing.

More, Thomas (1516/2003) Utopia, London, Penguin Classics.

O’Sullivan, M. (1953) Twenty Years a'growing, London, Oxford University Press. First published as Muiris Ó Súilleabháin, Fiche blian ag fás, Baile Átha Cliath, Oifig an tSoláthair, 1933.

Peters, P.F. (2006) Time, Innovation, and Mobilities, New York, Routledge. 
Pfeiff, M. (2007) 'The Spinach Armada: How the North gets its Groceries', The Walrus, November, www.walrusmagazine.com/articles/2007.11-field-notes-arctic-shopping.

Royle, S.A. (2001) Geography of Islands: Small Island Insularity, London, Routledge.

Sheller, M. \& Urry, J. (eds.) (2006) Mobile Technologies of the City, New York, Routledge.

Slack, J.D. \& Macgregor Wise, J. (2005) Culture + Technology, New York, Peter Lang.

Simpson, J. (2008) 'Warning: The Boom in our West is both a Lure and a Trap', The Globe and Mail (Canada), April 26, A23.

Sioui, G.E. (1994) Les Wendats: Une civilisation méconnue, Sainte Foy QC, Les Presses de l’Université Laval.

Star, S.L. (1999) 'The Ethnography of Infrastructure', American Behavioural Scientist, Vol. 43, No. 3, pp. 377-391.

Steinberg, P.E. (2001) The Social Construction of the Ocean, Cambridge, Cambridge University Press.

Steinberg, P.E. (2005) 'Insularity, Sovereignty, and Statehood: The Representation of Islands on Portolan Charts and the Construction of the Territorial State', Geografiska Annaller, Vol. 87B, No. 4, pp. 253-265.

Thevet, A. (1983) Les singularités de la France Antarctique, Le Brésil des Cannibales au $X V I^{e}$ siècle. Choix de textes, introduction et notes de Frank Lestringant, Paris, La Découverte/Maspéro.

Trudel, M. (1968) Atlas de la Nouvelle-France, Québec, Les Presses de l'Université Laval.

Turner, B.S. (2001) 'Social Fluids: Metaphors and Meanings of Society', Body \& Society, Vol. 9, No. 1, pp. 1-10.

Van der Zwaag, D. \& Lamson, C. (eds.) (1990) The Challenge of Arctic Shipping: Science, Environmental Assessment and Human Values, Montreal/Toronto, McGill-Queen's University Press.

Watt-Cloutier, S. (2006) 'Don't abandon the Arctic to Climate Change', The Globe and Mail (Canada), May 24, A19.

Wynn, G. (2007) Canada and Arctic North America: An Environmental History, Santa Barbara CA, ABC-CLIO.

Urry, J. (2000) Sociology Beyond Societies, London, Routledge. 